\title{
БУТТЯ ЯК ПРОБЛЕМА СОЦІАЛЬНОї ФІЛОСОФІї
}

\section{О.В. Кулєшов}

Te, які плани і програми здійснюються в суспільстві, залежить від того, як сприймається і розуміється суспільство суб'єктами соціальної дії. Структура цього розуміння має певну «глибину», тобто виявляе наявність різних поняттєвих шарів, що визначається, у свою чергу, тим, які поняття використовуються для опису суспільства, який сенс їм надається. Філософія з її граничними абстракціями - логічно припустити - може запропонувати і граничну глибину розуміння. Філософствування про суспільство, отже, дає надію на відкриття неочікуваних і далекосяжних перспектив. Ця вічна i, можна сказати, природна спокусливість філософії часто викликає недовіру, пробуджені нею сподівання здаються надмірними і тоді філософію намагаються убрати у певні рамки, показати їй на її досить скромне місце в суспільному житті, місце, яке позбавляє амбіційності. Втім, чи залишається в такому разі філософія філософією? Чи реалізує вона свої потенції щодо суспільства? Не виключене і більш далекосяжне питання: а чи існує сьогодні взагалі соціальна філософія?

Серед декількох парадигм сучасної соціальної філософії буде доцільним звернути увагу на три, як здається, найбільш репрезентативні. Саєнтистська філософія, навіть відмовляючись від позитивізму у соціальних науках як від пройденого етапу, все ж таки керується позитивістською установкою, згідно з якою філософія, оскільки вона $є$ знанням, а не довільними міркуваннями, є знанням вторинним стосовно наукового знання. Таким чином, йдеться не про філософію суспільства, а про філософію соціальних наук. Соціальна філософія в такому її різновиді позиціонує себе як метатеорія соціології (див. [2]).

Актуальні проблеми духовності

(Відп. ред.: Я.В. Шрамко)

Кривий Ріг (2007), 329-341 
Це особлива мова другого порядку, в якій обговорюються соціологічні поняття, формулюються приховані припущення, висловлюються методологічні принципи, оцінюється баланс між онтологічним і епістемологічним спрямуванням соціологічних теорій. Філософія зводиться до сукупності процедур, що прояснюють теоретичні конструкції соціологів. Не маючи власної емпіричної бази, соціальна філософія, таким чином, не займається безпосередньо суспільством.

Досить поширеною в сучасній російській та українській філософії $\epsilon$ парадигма, яку можна назвати постмарксизмом. Висловлюючи досить гостру критику окремих положень соціальної теорії Маркса, філософи принципово не відходять від базових принципів, які склались в історичному матеріалізмі. Зокрема це стосується і статусу соціальної філософії. Вона ототожнюється з теоретичної соціологією. Філософія, 3 цього погляду, трактує загальні питання суспільствознавства ( $\mathrm{Co}-$ ціальна філософія, безумовно, виступає в цій своїй якості наукою про найбільш загальні (всезагальні) закономірності розвитку суспільного життя» $[9$, с.6]). Оскільки ті ж питання розглядає і теоретична соціологія, між нею і соціальною філософією немає якісної межі. Взагалі ж чіткого критерію визначення тих питань, які слід вважати загальними, які є більш філософськими, ніж конкретно соціологічними тут немає. Здається, що в цьому різновиді соціальної філософії обговорюється коло тем, які потрапили до неї лише за традицією, не маючи інших підстав для цього: суспільне виробництво, відносини суспільства та природи, суспільства та особистості, об'єктивне та суб'єктивне в суспільних відносинах, структура суспільства тощо. Чому ці питання $\epsilon$ філософськими, а не конкретно-науковими, сказати важко.

Третьою парадигмою сучасної соціальної філософії, на яку слід звернути увагу, є постмодерністська. У цьому способі філософствування відмінності між соціальною філософією і конкретними соціальними науками втрачають будь-яке значення, уходять з кола безпосередньої уваги та інтересу філософа, стають другорядними, нецікавими. Ці відмінності трактуються як дискурсивні особливості відмінних текстів, як правила, за якими грає автор із символами, що складають текст. Але ж і самі ці правила стають об'єктом гри, випробування на можливість їх деконструкції, тобто переконструювання, деформації, пошуків межі комбінаторних можливостей мовних засобів і стильового ускладнення. Суспільство позбавляється якості предмета дослідження і стає засобом продукування висловлювань, які мають виражати глибинні творчі інтенції філософів і які не піддаються верифікації.

Слід зауважити, що метою статті не $є$ ні проста констатація опи- 
саних парадигм соціально-філософського знання, ні їх спростування. Безумовно, що всі вони не лише мають право на існування, але і додають дещо суттєве до наших знань про навколишню дійсність і про себе. Разом з тим, знайомство з філософською літературою викликає відчуття того, що сучасній філософії взагалі і соціальній філософії зокрема бракує ефективності, дієвості і подолати цей брак вона може лише через самовизначення, через досягнення певного суверенітету, незалежності від конкретних наук з одночасним збереженням її теоретичної строгості і визначеності.

Метою статті є формулювання принципів, які б могли бути покладені в основу більш філософоцентричної, більш філософськи рафінованої і водночас цілком теоретично коректної соціальної філософії.

Бажання такої філософії спирається на переконання в тому, що філософія, принаймні в її найбільш розвинутій, завершеній і досконалій частині, $є$ наукою. Крім того, соціальна філософія має свій предмет, відмінний від предмета дослідження конкретних соціальних наук, і свою емпіричну базу, яка лише зовні схожа на емпіричну базу соціології. Соціологія досліджує соціальні явища, які позначаються специфічними термінами: соціальні відносини, соціальні діï, соціальні функиії, соціальні інститути, соціальні спільноти (або групи) тощо. Предметом філософії є сфера буттл і сфера сущого. (Зазначу, що таке предметне визначення не викидає з філософії епістемологію, праксеологію, філософську методологію - ці галузі досліджують відношення людини до предметної області філософії. Ту ж саму роль стосовно своїх предметних областей виконує методологія конкретних наук.) Варто називати дослідження буття онтологією, а дослідження сущого метафізикою. Таким чином, соціальну філософію слід, з цієї точки зору, розглядати, перш за все, як онтологію соціального буття i метафізику соціальних об'єктів.

Відмінність між мовою соціальних наук і мовою соціальної філософії очевидна. Для соціології вищеназвані поняття суспільних явищ є вихідними, інтуїтивно зрозумілими або визначеними через інші поняття цього ряду. Для філософії соціологічні поняття мають бути похідними від онтологічних та метафізичних категорій. Спеціальні наукові поняття можна описати і пояснити в системі мови певної науки. Філософські поняття так пояснити не можна. Їх можна описати і пояснити лише в системі мови філософії. Втім цією філософською мовою можна виразити і спеціальні наукові поняття, твердження і факти науки. Філософська мова $є$ першопорядковою, більш елементарною відносно мови конкретних наук. Інакше кажучи, вона займає природне 
місце метамови наук. Тому філософія здатна входити до області, яка досліджується конкретною наукою для її опису і пояснення гранично загальними, елементарними поняттями.

Це не означає, що філософія повинна досліджувати, зокрема, соціальну реальність поза соціальними відносинами, інститутами, суб’єктами, діями людей і т.д. Це означає лише те, що філософія має інтерпретувати означені соціальні явища в онтологічних та метафізичних поняттях. Лише такий опис є дійсно філософським. Формулюючи більш жорстко, можна сказати, що філософію не повинне безпосередньо цікавити суспільство, його частини і сторони - навіть найзагальніші. Філософія займається буттям і сущим, лише буттям і сущим, зокрема, у вигляді суспільства та його елементів. Суспільство та його елементи як прояви буття і різновиди сущого є особливим, унікальним і неповторним предметом соціальної філософії.

Залишається питання про емпіричну базу соціально-філософського дослідження. Не виключено, що такої немає або вона збігається з базою соціальних наук. Найабстрактніші категорії буття і сущого прийнято вважати плодом витонченого розумового конструювання. Здається, що ці розумові конструкти надто далеко відстоять від чуттєвих емпіричних фактів, результатів спостережень, опитувань, вимірювань. Втім, звернемо увагу на твердження сучасної когнітивістики: чисто емпіричних фактів не існує. Те, що називають емпіричним, фактами, є завжди наслідком співпраці почуттів, інтуїції і розуму, застосуванням певних когнітивних схем, прототипів, способів категоризації. В такому разі емпіричне можна визначити як елементарний структурний рівень схем сприйняття людиною дійсності. Буття і суще відповідають такому визначенню i, отже, є первинними емпіричними фактами. Власний досвід людини вказує на будь-які теоретичні міркування, що значить бути або не бути, показує, що існування передбачає дещо таке, що існує. Буття суспільства є емпіричним фактом, воно відчувається постійно (і часто досить неприємно) і з цього факту має виходити соціальна філософія.

Зрозуміло, що мало просто виходити з певних фактів, треба фіксувати їх відмінності, класифікувати, описувати їх, будувати теоретично обгрунтовану систему, а для здійснення таких завдань має бути готовий до застосування розвинений поняттєвий апарат. В цьому плані кращі справи з метафізикою. Різноманітне і дискретне суще легко поділяється на роди, види, категорії. 3 часів «Метафізики» Аристотеля поняттєвий апарат метафізики лише збагачувався і вдосконалювався. Опис соціальних об’єктів, їх різновидів і структурних відносин не зда- 
ється принципово неможливою справою.

Більше питань викликають можливості соціальної онтології. Тому далі ми зосередимось на проблемі розуміння суспільства як особливого різновиду буття. Проблемою взагалі є, чи можна говорити про специфіку буття, а отже, чи правильно відокремлювати соціальне буття як особливу реальність? Або ж (відповідно до розуміння буття I. Кантом) і справді поняття буття нічого не додає до поняття суспільства? В такому випадку буття суспільства таке саме як буття природи, людини, окремих природних чи ідеальних об'єктів і, говорячи про буття суспільства, ми неминуче будемо говорити не про буття, а про суспільство. Якщо так, виникають сумніви в окремому від методів і концепцій соціології філософському дослідженні суспільства. Безумовно, це спонукає до аналізу проблеми.

Можливості онтологічного опису суспільства обмежені загальним розумінням буття у філософії. Суспільство існує, так само існують всі його інститути, відносини, спільноти, структури і цей факт може бути нетривіальним лише для філософії. Відокремити суспільне буття від того, що є суспільством - завдання, яке апелює до філософського масштабу мислення. Втім доцільність відокремлення буття від сущого завжди потребує виправдання і в цьому виправданні вже має вбачатись певне розуміння буття. Для античної філософії розрізнення буття і сущого, як можна припустити, було не дуже актуальним. Чіткого термінологічного поділу в текстах античних філософів не простежується. Відомо, що найбільш поширений буттєвий термін оуsia y Платона, Аристотеля та інших авторів тієї епохи позначає іноді буття, а іноді - дійсно суще [6, с. 54]. Зрозумілим це стає, якщо врахувати, що вихідним пунктом для античної онтології залишалась гранична абстракція Парменіда, в якій буття-суще $є$ нерозрізненною єдністю [10, с. 290-291]. Будь-яке розрізнення, розщеплення єдиного цілого руйнує логічну конструкцію Парменіда. Але така несуперечливість і монолітність образу буття-сущого забезпечена шляхом вилучення небуття, що, як відомо, призводить до багатьох логічних парадоксів і, зокрема, ставить під сумнів існування спостерігача і свідка буття, тобто нас самих. Допущення ж небуття неминуче спонукає до розрізнення буття і сущого. Те, що існує, принаймні, може і не існувати, а це означає, що об'єкти виходять за межі стану буття, а стан буття виходить за межі об'єктів. Особливим предметом для роздумів ця ситуація стала лише для філософів кінця XIX - початку XX століття зі школи Ф. Брентано (зокрема для Е.Гуссерля і А. Мейнонга). Втім, порівняно чітке розрізнення буття і сущого притаманне вже середньовічній 
християнській філософії. Слід думати, що для християнського мислення і світосприйняття, в якому Бог контрастно протиставлений світу, таке розрізнення було більш природним. В томізмі Бог $є$ саме буття [6, с. 160]. Буття є сутністю Бога, тоді як у створених Богом речах сутність передує існуванню. В томізмі ж намічено і поділ самого буття на абсолютне творче буття Бога і екзистенцію, існування окремих речей.

Таким чином, виявилось, що, відокремлюючись від сущого, саме буття стає в собі неоднорідним, допускає різні тлумачення. Думається, що цей факт є вирішальним для перспектив побудови соціальної онтології. В такому контексті варто звернути увагу, що в різних філософських концепціях простежуються, принаймні, дві принципово відмінних парадигми буття.

Якщо слідувати вдалій метафорі М. Хайдеггера, буття «просвічує» крізь суще. Лише у розривах між сущим людині стає видимим буття. Але, вдивляючись в суще у пошуках буття, ми відкриваємо в собі здатність дивитись на буття з різних сторін, берегів сущого. Останнє постає перед нами у своїй монолітності як своєрідний вододіл буття. По один бік проглядає буття, яке належить сущому, по другий - буття, яке передбачає суще. Відмінність цих онтологічних сфер далеко не малозначуща і не тривіальна. Вона спонукає до двох принципово відмінних тлумачень буття. Ми маємо вибирати 3 двох альтернативних буттєвих образів. Або це буття, яке просто свідчить про суще, означає його наявність, його фактичність, те, що воно є сущим, а не нічим. Або ж це буття, яке робить можливим, необхідним і дійсним суще; буття, яке творить суще не лише як суще, але як таке суще, яким воно $є$. Це буття, яке можна назвати структурною основою сущого. Отже, ми протиставляємо, застосовуючи середньовічну термінологію, буття post res i буття ante res, інакше кажучи буття після речей, після сущого і буття до речей, до сущого. Зрозуміло, що мається на увазі не часова і не фізична та, мабуть, і не причинно-генетична послідовність, а структурно-логічні відношення. Перше тлумачення передбачає буття безякісне, просте, «невизначене безпосереднє», виражаючись словами Гегеля $[4$, с. 217]. Чисте буття, яке може відрізнятись лише тим сущим, якому воно належить і служить; буття, в якому всі внутрішні поділи, відмінності, розмежування, розрізнення йдуть через суще. Протилежному ж тлумаченню відкривається буття, яке приховує, вміщує, зберігає в собі внутрішні відмінності, що є джерелом його різноякісності. Якості буття постають потенціями, в іншому сенсі-орієнтирами, ескізами, схемами, «шифрами» (пригадаємо і дзеркально перевернемо 
цей термін К.Ясперса) певного сущого; буття завжди має схильність до певного сущого, це взагалі буттл до сущого (хоча не безпосередньо буття сущого, що є вторинним з такої точки зору).

Першу парадигму можна назвати парадигмою безякісного буття. Воно, з такого погляду, з необхідністю $є$ буттям чогось, це наявність певного сущого. Таким постає буття речей в середньовічному томізмі, їх екзистенція, яка протиставляється абсолютному буттю Бога. Відрізняючи існування від сутності середньовічні мислителі надавали буттю речей значення простої реальності, яка $є$ лише частиною композиції сутності та існування і позбавляється сенсу поза сутністю. В крайньому випадку, як це було у Дунса Скота, існування ототожнюється з сутністю [6, с. 162]. Таке розуміння буття в його застосуванні до світу, в якому існує людина, було перейнято у середньовічної філософії філософією Нового часу. Для Декарта буття $\epsilon$ атрибутом сущого, буття ототожнюється з існуванням [5, с. 336,609$]$. Виводячи буття 3 мислення, Декарт шукає не буття як особливу реальність, але реальність сущого. Його категоріальні визначення буття як випадкового, необхідного, досконалого або вічного $€$ зовнішніми характеристиками, зумовленими відповідними якостями речей, що існують $[5$, с. 319,475$]$. Так само для Гегеля буття $\epsilon$ абстрактним, пустим, нерефлектованим поняттям, індиферентною тотожністю [4, с. 215-217]. Гегелівське буття, отже, не охоплює всього, а входить до всього як момент розгортання, реалізації сущого, яке у своїй повноті постає як абсолютна ідея. Трансцендентальний ідеалізм Канта взагалі не передбачає абсолютного плану буття, оскільки ми не можемо знати, що є буття в абсолютному сенсі. Емпірична ж реальність є для Канта конструктом, зумовленим двома чинниками - об'єктивним, тобто феноменами, і суб'єктивним апріорними схемами чуттєвості і мислення. Існування постає як форма суб'єкт-об'єктних відносин і тому не має сенсу говорити про буття речей самих по собі. Буття є особливим способом поєднання речей. Не випадково Кант включає буття до таблиці модальних категорій, ототожнюючи його з дійсністю і протиставляючи модальностям можливості і необхідності [7, с. 167-170]. Таке не онтологічне, а логічне розуміння буття - цілком в традиції Канта - притаманне саєнтистським напрямам філософії XX ст., зокрема аналітичній філософії. Таким чином, парадигма безякісного буття $\epsilon$ досить поширеною у філософії, орієнтованій в бік емпіричного або ширше - спеціально-наукового дослідження. Безякісне буття, вочевидь, $\epsilon$ зручним для такого дослідження, бо воно прозоре для сущого (в цьому сенсі воно дійсно є «чистим» буттям). Воно не додає до сущого нічого крім себе. Таке буття передбачає 
лише дві можливості-бути або не бути. Буття є дійсністю певного сущого, а дійсність - це зв'язок через дію. Буття пов'язує суще, але не родо-видовими або якісно-кількісними відносинами, а відносинами аналогії (на що звертав увагу ще Аристотель). В такому бутті немає внутрішніх відмінностей, різновиди буття за такої парадигми - це не прояв різних аспектів самого буття, а репрезентація різних аспектів сущого. Категоріальні визначення буття (буття можливе, необхідне, якісне, кількісне тощо) є зовнішньо визначеним буттям. Можливе буття, наприклад, в даному випадку, не відрізняється від буття можливості і т. д. Таким чином, одне буття є відмінним від іншого не тому, що має іншу структуру, а тому, що відрізняється те, що $є$ (існує). Буття просто робить дійсним цю відмінність і це єдине призначення і виправдання цієї філософської категорії.

Іншою парадигмою - її ми назвемо парадигмою якісного буттяпередбачається буття як особлива реальність, що логічно і структурно передує сущому. Абсолютне буття як окремий предмет мислення, якесь всезагальне, самостійне і творче начало вже присутнє в античній філософії. Буття Платона є окремим не лише як предмет мислення, буття і одиничні речі існують цілком роздільно. Буття є творчою силою і одночасно вищою метою, оскільки воно ототожнюється з благом, красою та істиною. Разом з тим це вище, дійсне буття $є$ конкретним, буття - це ідея і як ідея воно $є$ сущим. Таке відносне нерозрізнення буття і сущого змушує Платона шукати якогось начала, яке б поєднувало ідею буття з нижчими стосовно нього ідеями і це начало необхідно має бути поза-буттєвим. Результатами пошуків Платона стало надбуттєве Єдине (див. Платон «Парменід» [8, с. 346-411]), що значно ускладнило платонівську картину світу. Абсолютне буття Аристотеля, як це випливає 3 його «Метафізики», також конкретне-це дійсність, сама лише дійсність, якою є світовий розум [1, с.309-311]. Антична традиція поєднання абсолютного буття і сущого як такого виявилась цілком прийнятною і для середньовічної християнської філософії, де Бог трактувався як єдність буття та сутності. Зрозуміло, що такий синтез буття і сущого знімає проблему творчої потенції буття, його в собі різноманітності. Але виникає проблема надбуттєвої єдності, трансцендентного джерела буття і сущого. Щоправда, ця проблема втрачає актуальність у філософії Нового часу. Разом з тим, іде в непам'ять, говорячи словами М. Хайдеггера, і питання про буття як таке, точніше про те, що було названо якісним буттям. Лише онтологічні системи ХХ ст. такий погляд на буття відновлюють цілком свідомо і послідовно. Йдеться, перш за все, про онтології двох німецьких філософів ХХ ст. - М. Хайдеггера 
та Н. Гартмана. Протистояння буття і сущого, яке потребує гранично контрастного протиставлення $\epsilon$ аксіомою філософії М. Хайдеггера. Буття сущого можна описати через категоріальні визначення, але буття як таке цими визначеннями не зачіпається. Для буття як такого потрібна особлива мова, мова особливих понять - екзистенціалів. Серед екзистенціалів, відшуканих М. Хайдеггером, ми знаходимо часовість, історичність, власність і невласність, світність буття тощо. Ці якості буття утворюють його структуру. Поняття буттевих структур, буттевих модусів звичайні для мови Хайдеггера. При цьому буттеві структури передують структурам сущого («історичність розміщується до того, що іменують історією»-стверджує, наприклад, автор «Буття і часу» $[11$, с. 30]). Екзистенціали, властивості буття як такого накреслюють те суще, буттям якого воно є. Буття визначає, яким має бути суще [11, с. 18]. Н. Гартман також намагається відновити питання про буття як таке після періоду, який він називає двохсотрічним сном онтології [3, с. 71]. Він обирає інший шлях до буття ніж Хайдеггер, критикуючи останнього за те, що той знаходить вихідний пункт своєї онтології в людському бутті, адже буття, на думку, Н. Гартмана, байдуже до будь-якого знання або поведінки суб'єкта [3, с. 64]. Але розуміння буття Н.Гартманом знаходиться в межах тієї ж парадигми, що і у Хайдеггера. В обох філософів ми знаходимо принципове відокремлення буття від сущого. Одним з найважливіших понять онтології Н. Гартмана $\epsilon$ поняття способів буття. Він говорить про ідеальне i реальне, ось-буття (буття індивідуальне) і так-буття (буття загальне) як про відмінні способи буття. Йдеться також про ступені буття і про міру буття [3, с. 204-209]. Про способи, ступені і міри буття можна говорити окремо від сущого, вони безпосередньо пов'язані з буттям і лише опосередковано - з сущим. Взагалі для Н. Гартмана характерне дискретне, диференційоване бачення різних онтологічних сфер, окремих світів: буття і сущого, реального та ідеального буття тощо. Ідеальне являє себе через реальне, звідси ідеальне буття зумовлює реальне $[3$, c. 548-558]. Так само буття як таке являє себе через суще, але звідси, за логікою Н. Гартмана, постає залежність сущого від буття.

Наведені думки філософів досить явно свідчать, що парадигма якісного буття грунтується на визнанні буття в певному сенсі первинною світовою реальністю. Зрозуміло, ця реальність не існує у фізичному відриві від сущого. Буття неможливо виявити способом спостереження або інструментального виокремлення з сущого. Емпірично воно злите з сущим, але онтологічно (у своєму існуванні і найзагальніших формальних відношеннях) є дещо особливе. Залежність буття від су- 
щого зворотна: буття визначає суще, воно і $є$ тим, що визначає суще і саме тому неможливе без сущого. Втім воно не залежить від сущого генетично, воно не утворюється сущим. Якісне буття є продуктивною реальністю, воно містить в собі потенції, які реалізуються сущим. Те, що закладене в бутті, є можливим для сущого. Буття-це поле можливостей сущого. Суще, таким чином, можна пояснити, виходячи 3 буття. Буття - це обрій або межа сущого. Те, що суперечить буттю, не може бути. Те, що є, випливає з накресленого буттям проекту. Буття в структурно-логічному сенсі переходить у суще, причому різними способами, що і утворює різні форми (види, роди) сущого. Способи буття внутрішньо обумовлені. Звідси різновиди буття - це не одне й те саме буття відмінного сущого, а відмінності в самому бутті, зумовлені його різноаспектністю, структурністю. В самому бутті (поза будьяким сущим) можна знайти різні сторони або аспекти. Відношення цих різних аспектів утворюють відмінності в реалізації буття, переходах його до сущого, тобто у способах бути. Буття різноманітне в собі, відмінність, можливо, і $є$ визначенням буття. Таким чином, буття 3 цієї точки зору постає як особлива перед-структура світу, ми можемо говорити про різне буття, виявляти його якості, якісні різновиди, для чого потрібна особлива мова буттєвих понять.

Парадигма якісного буття дає змогу бачити і в людському суспільстві особливий спосіб буття, що грунтується на особливій структурі його внутрішніх якостей. Разом з тим, слід констатувати, що у дотеперішній соціальній філософії ця парадигма значного розвитку не мала. Соціальні філософи досить часто використовують поняття соціального бутmл, можна навіть говорити про галузь соціальної онтології. Але буття розуміється у першому з наведених вище значень безякісного буття. Коли йдеться про суспільне буття, то воно ототожнюється з буттям суспільства. Отже, в цьому словосполученні термін бутmя елімінується, стає порожнім додатком і йдеться фактично лише про суспільство.

Якщо соціальну філософію розуміти як теоретичну соціологію, то вона досліджує соціальне суше, яке відрізняється лише своєю загальністю. Найзагальніші соціальні явища - відношення, інститути, спільноти, а також закономірності, причинні і структурні зв'язки є тим, що існує і що розглядається, як правило, поза особливостями свого існування. Буття не відокремлюється від сущого. Соціальна філософія як метатеорія соціальних наук також, хоча і непрямо, займається соціальним сущим. Шляхом обгрунтування наукових поняттєвих конструкцій, виявлення їх емпіричних або теоретичних джерел ми ще не 
досягаємо специфічних рис буття соціальних явищ, але краще окреслюємо їх, об'єктивуємо, визначаємо їх місце в загальній структурі соціальної реальності. Нарешті, соціальна філософія як гра точок зору і знакових систем стосується соціального на рівні соціальної мови, комунікації, висловлювань. Структура соціальної реальності, в такому разі, залежить від відношень між соціальними знаками, цінностями, a, отже, в основі ми знаходимо знов і знов якесь суще.

Дослідження буття суспільства не з точки зору буття, а з точки зору лише суспільства та його структурних елементів - інститутів, відносин, спільнот - цілком прийнятний і продуктивний спосіб дослідження. Але є декілька філософських проблем, які такий спосіб осмислення суспільства не розв'язує. Йдеться, зокрема, про неможливість визначити межу між власне філософським і соціологічним рівнем дослідження. Більша загальність, більша методологічна спрямованість або більша текстоцентричність соціального дослідження, на яку претендує філософія суспільства, цілком може бути здійснена в рамках загальної соціології. Соціологія, як і будь-яка наука, має у своєму розпорядженні засоби, які дозволяють їй виходити за наявні межі, розширювати масштаб охоплення дійсності, здійснювати саморефлексію. Залишається відкритим також питання обгрунтування обраних соціальною теорією базових понять, принципів, самих об'єктів дослідження. Чому соціальна дійсність структурується таким чином, а не інакше, чому увага звертається на соціальні відносини або соціальну дію, на природу людини або процеси комунікації, залишається значною мірою питанням очевидності та інтуїції. Філософія, яка б мала, як граничне знання, знаходити онтологічне підгрунтя для основоположень соціальних наук, в цих випадках просто користується ними або пояснює їх в термінах, які не виходять за межі соціології. Ще одна проблема, яку важко розв'язати з позиції ототожнення буття і сущого, випливає 3 модального поділу реальності на дійсне, можливе і необхідне. Точка зору сущого $є$ ефективною у виявленні того, що $\epsilon$. Те, що може бути в суспільстві і з суспільством потребує більш широкого погляду, виходу до якоїсь основи сущого. Соціальна необхідність, у свою чергу, як те, що $є$ імперативним, належним для суспільства і суспільної людини, не простежується взагалі через наявне суще. Можна встановити зв'язки між соціальними явищами, знайти засоби, які краще відповідають певній меті, виявити те, що вважається цінним для людства. Але в чому смисл цієї соціальної мети і цих соціальних цінностей ми таким чином ще не встановимо.

Для наближення до такого осмислення суспільства потрібно, оче- 
видно, зробити вихідним пунктом буття, як передумову сущого, якісне буття. Потрібне розуміння того, що сенс існування будь-чого, знаходиться в самому існуванні. Лише звернення до буття виявляє абсолютну необхідність, а також і відносну цінність певних соціальних явищ. Соціальне буття дає можливість найширшого, граничного обгрунтування об'єктів соціального дослідження. Є змога визначати їх межі, структурувати і порівнювати їх не через самих себе, а з якоїсь основи. Буттєва точка зору також якісно відокремлює предмет соціально-філософського дослідження від предметів конкретних соціальних наук. Відмінності стають помітними вже на рівні теоретичної мови оскільки філософське дослідження в цьому випадку є онтологічним (в буттєвих термінах) описом соціальної реальності, репрезентованої соціальним сущим. Останнє стає не засобом опису, а тим, що описується філософською мовою.

Зрештою, варто зробити висновок, що соціальна онтологія як окрема від соціологічного теоретизування галузь $є$ перспективним напрямом соціально-філософських досліджень. Цей напрям може розширити наш погляд на суспільство, дати нову перспективу у визначенні планів і програм, що здійснюються в суспільстві, того, як сприймається і розуміється суспільство суб'єктами соціальної дії. I в цьому сенсі плідним виглядає використання парадигми якісного буття, виробленій у філософській онтології минулого і сучасності.

\section{1 Бібліографія}

[1] Apистотель. Сочинения в 4 т. - Т. 1.- М.: Мысль, 1976.

[2] Aутвейm У. Реализм и социальная наука // Социо-логос. - М.: Прогресс, 1991.- С. 141-159.

[3] Гартман Н. К основоположению онтологии. - СПб: Наука, 2003.

[4] Гегель Г.-В.-Ф. Энциклопедия философских наук.- Т. 1.-M.: Мысль, 1975.

[5] Декарт Р. Сочинения в 2 т. - Т. 1.- М.: Мысль, 1989.

[6] Доброхотов А.Л. Категория бытия в классической западноевропейской философии. - М.: Изд. Моск. ун-та, 1986.

[7] Кант И. Критика чистого разума. - СПб.: Тайм-Аут, 1993. 
[8] Платон. Собрание сочинений в 4 т. - Т. 2. - М.: Мысль, 1993.

[9] Социальная философия. Учебник. / Под редакцией И.А. Гобозова. - М.: Издатель Савин С.А., 2003.

[10] Фрагменты ранних греческих философов. - М.: Наука, 1989.

[11] Хайдеггер М. Бытие и время. - M.: Ad Marginem, 1997. 